\title{
Front Matter: Volume 9653
}

, "Front Matter: Volume 9653," Proc. SPIE 9653, Target and Background Signatures, 965301 (14 November 2015); doi: 10.1117/12.2227230

SPIE. Event: SPIE Security + Defence, 2015, Toulouse, France 


\section{PROCEEDINGS OF SPIE}

\section{Target and Background Signatures}

\section{Karin U. Stein}

Ric H. M. A. Schleijpen

Editors

23-24 September 2015

Toulouse, France

Sponsored by

SPIE

Cooperating Organisations

European Optical Society

Optitec (France)

Route des Lasers (France)

Published by

SPIE 
The papers in this volume were part of the technical conference cited on the cover and title page. Papers were selected and subject to review by the editors and conference program committee. Some conference presentations may not be available for publication. Additional papers and presentation recordings may be available online in the SPIE Digital Library at SPIEDigitallibrary.org.

The papers reflect the work and thoughts of the authors and are published herein as submitted. The publisher is not responsible for the validity of the information or for any outcomes resulting from reliance thereon.

Please use the following format to cite material from these proceedings:

Author(s), "Title of Paper," in Target and Background Signatures, edited by Karin U. Stein, Ric H. M. A. Schleijpen, Proceedings of SPIE Vol. 9653 (SPIE, Bellingham, WA, 2015) Six-digit Article CID Number.

ISSN: 0277-786X

ISSN: 1996-756X (electronic)

ISBN: 9781628418637

Published by

SPIE

P.O. Box 10, Bellingham, Washington 98227-0010 USA

Telephone +1 3606763290 (Pacific Time) · Fax + 13606471445

SPIE.org

Copyright @ 2015 , Society of Photo-Optical Instrumentation Engineers.

Copying of material in this book for internal or personal use, or for the internal or personal use of specific clients, beyond the fair use provisions granted by the U.S. Copyright Law is authorized by SPIE subject to payment of copying fees. The Transactional Reporting Service base fee for this volume is $\$ 18.00$ per article (or portion thereof), which should be paid directly to the Copyright Clearance Center (CCC), 222 Rosewood Drive, Danvers, MA 01923. Payment may also be made electronically through CCC Online at copyright.com. Other copying for republication, resale, advertising or promotion, or any form of systematic or multiple reproduction of any material in this book is prohibited except with permission in writing from the publisher. The CCC fee code is 0277-786X/15/\$18.00.

Printed in the United States of America.

Publication of record for individual papers is online in the SPIE Digital Library.

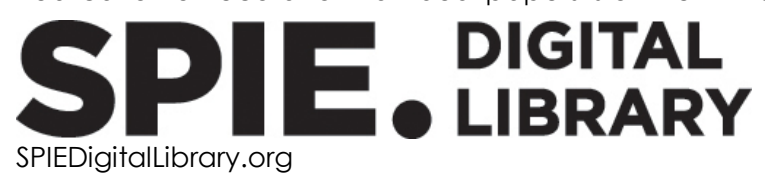

Paper Numbering: Proceedings of SPIE follow an e-First publication model, with papers published first online and then in print. Papers are published as they are submitted and meet publication criteria. A unique citation identifier (CID) number is assigned to each article at the time of the first publication. Utilization of CIDs allows articles to be fully citable as soon as they are published online, and connects the same identifier to all online, print, and electronic versions of the publication. SPIE uses a six-digit CID article numbering system in which:

- The first four digits correspond to the SPIE volume number.

- The last two digits indicate publication order within the volume using a Base 36 numbering system employing both numerals and letters. These two-number sets start with 00, 01, 02, 03, 04, $05,06,07,08,09,0 A, 0 B \ldots$. 0Z, followed by 10-1Z, 20-2Z, etc.

The CID Number appears on each page of the manuscript. The complete citation is used on the first page, and an abbreviated version on subsequent pages. 


\title{
Contents
}

\author{
$\checkmark \quad$ Authors \\ vii Conference Committee \\ ix Introduction
}

\section{SESSION 1 CAMOUFLAGE EFFECTIVENESS}

965302 A systems approach to stealth on the ground revisited (Invited Paper) [9653-1]

965303 Evaluation criteria for spectral design of camouflage [9653-2]

965304 Camouflage effectiveness of static nets in SAR images [9653-3]

965305 Discriminating between camouflaged targets by their time of detection by a human-based observer assessment method [9653-4]

965306 Adaptive camouflage in the VIS and IR spectral range: main principles and mechanisms (Invited Paper) [9653-5]

\section{SESSION 2 SCENE MODELLING}

965307 New impressive capabilities of SE-workbench for EO/IR real-time rendering of animated scenarios including flares [9653-6]

965308 Multisensors signature prediction workbench [9653-7]

965309 Image simulation for HardWare In the Loop simulation in EO domain [9653-8]

$96530 \mathrm{~A}$ Simulation of atmospheric and terrestrial background signatures for detection and tracking scenarios [9653-9]

$96530 \mathrm{C}$ Modelling the infrared and radar signature of the wake of a vessel [9653-11]

\section{SESSION 3 SIGNATURE PHENOMENOLOGY}

9653 OD Spectral analysis of the vegetative background in the NIR and SWIR spectral range [9653-12]

9653 OF The Havemann-Taylor Fast Radiative Transfer Code (HT-FRTC) and its application within Tactical Decision Aids (TDAs) [9653-15]

9653 OG FTOM-2D: a two-dimensional approach to model the detailed thermal behavior of nonplanar surfaces [9653-16] 
$9653 \mathrm{OH}$ Comparison of the relative merits of the midwave and longwave infrared bands for various target types using detected thermal contrast [9653-17]

\section{SESSION 4 HYPERSPECTRAL SIGNATURES}

9653 ol An approach to optimal hyperspectral and multispectral signature and image fusion for detecting hidden targets on shorelines (Invited Paper) [9653-18]

9653 0J Assessment of target detection limits in hyperspectral data [9653-19]

9653 OK Utilization of hyperspectral camera for determination of camouflage surfaces spectral characteristics homogeneity [9653-20]

$9653 \mathrm{OL}$ Analysis of exploitable spectral features of target and background materials [9653-21]

\section{SESSION 5 PROCESSING}

$9653 \mathrm{OM}$ Precision targeting in guided munition using IR sensor and $\mathbf{M m W}$ radar [9653-22]

9653 ON Real-time object detection and tracking in omni-directional surveillance using GPU [9653-23]

965300 RecceMan, an interactive recognition assistance for image-based reconnaissance: synergistic effects of human perception and computational methods for object recognition, identification, and infrastructure analysis [9653-24]

9653 OP Experimental application of simulation tools for evaluating UAV video change detection [9653-25]

SESSION 6 HUMAN OBSERVER PERFORMANCE

9653 OR Human factors of target detection tasks within heavily cluttered video scenes [9653-27]

9653 OS Disruptive coloration tricks the human eye: a study of detection times of two near-similar targets in natural backgrounds [9653-30]

9653 OT Evaluation of statistical methods for the evaluation of observer trials for the assessment of the effectiveness of signature measures [9653-28]

$96530 \mathrm{U}$ Performance of target distinctness metrics evaluated against colour and monochromatic photosimulation results [9653-29]

$9653 \mathrm{OV}$ A comparison between maritime field observations and photosimulation for developing and validating visible signature evaluation tools [9653-31] 


\section{Authors}

Numbers in the index correspond to the last two digits of the six-digit citation identifier (CID) article numbering system used in Proceedings of SPIE. The first four digits reflect the volume number. Base 36 numbering is employed for the last two digits and indicates the order of articles within the volume. Numbers start with 00, 01, 02, 03, 04, 05, 06, 07, 08, 09, 0A, 0B...0Z, followed by 10-1Z, 20-2Z, etc.

Åkerlind, Christina, 03

Andersson, Kent E., 02

Angele, Susanne, 00

Arya, H., OM

Baláž, Teodor, OK

Bartelsen, Jan, OP

Bartos, B., OG

Boehler, J., OJ

Bostater, Charles R., 01

Cathala, Thierry, 07, 08, 09

Culpepper, Joanne B., OU, OV

Depraz, Florian, ON

Devecchi, Bernadetta, OC

Dunau, Patrick, OT

El Bekri, Nadia, 00

Fagerström, Jan, 03

Fitz, Daniel, OT

Furnell, Alistair, OV

Gross, W., 0J

Hablani, H. B., OM

Haelke, Bruno, 00

Hallberg, Tomas, 03

Havemann, Stephan, OF

Huber, Samuel, OR

Hult, Gunnar, 02

Jersblad, Johan, 04

Jobánek, Adam, OK

Kariis, Hans, 02, 03

Kneubuehler, M., 0J

Larsson, Christer, 04

Latger, Jean, 07, 08, 09

Leblebici, Yusuf, ON

Le Goff, Alain, 07

Middelmann, W., OJ

Oechslin, R., 0J

Ott, Beat, ON

Peinsipp-Byma, Elisabeth, 00

Popovic, Vladan, ON

Racek, František, OK

Ruckhäberle, Martin, 00

Saur, Günter, OP

Schilling, H., OJ

Schwarz, Alexander, 06

Schweitzer, Caroline, OA

Selj, Gorm K., 05, OS

Shao, Q. T., OV

Søderblom, M., 05

Sreeja, S., OM

Stein, Karin U., OA, OG, OT
Stewart, Seán M., $\mathrm{OH}$

Thelen, Jean-Claude, OF

van lersel, Miranda, OC

Wellig, Peter, OJ, ON, OR

Weyermann, J., OJ

Wheaton, Vivienne C., OU, OV

Winkelmann, Max, OD, OL

Wong, Gerald, OF 
Proc. of SPIE Vol. $9653965301-6$

Downloaded From: https://www.spiedigitallibrary.org/conference-proceedings-of-spie on 26 Apr 2023 Terms of Use: https://www.spiedigitallibrary.org/terms-of-use 


\title{
Conference Committee
}

\author{
Symposium Chair \\ David H. Titterton, UK Defence Academy (United Kingdom) \\ Symposium Co-chair \\ Reinhard Ebert, Fraunhofer-Institut für Optronik, Systemtechnik und \\ Bildauswertung (Germany) \\ Conference Chairs \\ Karin U. Stein, Fraunhofer-Institut für Optronik, Systemtechnik und \\ Bildauswertung (Germany) \\ Ric H. M. A. Schleijpen, TNO Defence, Security and Safety \\ (Netherlands) \\ Conference Program Committee \\ Hans M. Kariis, FOI-Swedish Defence Research Agency (Sweden) \\ Alexander Schwarz, Fraunhofer-Institut für Optronik, Systemtechnik \\ und Bildauswertung (Germany) \\ Miranda van lersel, TNO Defence, Security and Safety (Netherlands) \\ Peter Wellig, Armasuisse (Switzerland) \\ Session Chairs \\ 1 Camouflage Effectiveness \\ Hans M. Kariis, FOI-Swedish Defence Research Agency (Sweden) \\ 2 Scene Modelling \\ Karin U. Stein, Fraunhofer-Institut für Optronik, Systemtechnik und \\ Bildauswertung (Germany) \\ 3 Signature Phenomenology \\ Ric H. M. A. Schleijpen, TNO Defence, Security and Safety \\ (Netherlands) \\ 4 Hyperspectral Signatures \\ Alexander Schwarz, Fraunhofer-Institut für Optronik, Systemtechnik \\ und Bildauswertung (Germany) \\ $5 \quad$ Processing \\ Miranda van lersel, TNO Defence, Security and Safety (Netherlands)
}


6 Human Observer Performance

Peter Wellig, Armasuisse (Switzerland)

Proc. of SPIE Vol. $9653965301-8$

Downloaded From: https://www.spiedigitallibrary.org/conference-proceedings-of-spie on 26 Apr 2023 Terms of Use: https://www.spiedigitallibrary.org/terms-of-use 


\section{Introduction}

Sensor technology and signal processing have been covered by various conferences at European SPIE Security and Defense symposiums since 2004. Increases in spatial, spectral, and temporal resolution and detectivity have been presented on since then. The broadening of the spectral coverage has also opened the path to unprecedented sensor applications. Targets and background signatures have always been an important component of the work presented, but scientific contributions from this field of research have remained somewhat hidden within presentations at the different conferences.

The topic Targets and Backgrounds: Characterization and Representation was formerly covered by a conference series at the 2011 SPIE Defense and Security symposium in Orlando. Since then, a Targets and Backgrounds conference series has ceased to exist. A new conference was set up at the 2015 SPIE Security and Defence Symposium in Toulouse, and it was intended to re-establish a conference on Target and Background Signatures in order to provide a proper forum for the involved research community.

The high number of papers submitted to the 2015 conference indicates that the signature research community really welcomed the revival of a forum to present and discuss target and background signatures. The contributions come from several organizations located in 13 countries from Europe, North America, Asia, and Australia.

The conference was divided into six sessions:

- Camouflage effectiveness

- Scene modelling

- Signature phenomenology

- Hyperspectral signatures

- Processing

- Human observer performance

The session on Camouflage Effectiveness made clear that the effectiveness of signature reduction and signature management should be assessed at different levels:

- Tactics

- Capabilities

- System signature

- Signature features 
To help address all these levels, an integrated project approach is recommended- bringing different types of expertise together. This involves those in the industry working alongside researchers and military experts. The awareness of this approach set the tone for the conference.

The session on Scene Modelling showed excellent examples of current possibilities and capabilities in this field. Physical phenomena can be modelled with continuously increasing level of detail. An example of this was given in a presentation on effects of wakes on IR and radar signatures. However, despite the increase of computational power, physically accurate models can be very time consuming to run, and trade-offs have to be made between physical accuracy and computation time needed. This trade-off process will be supported by understanding the level at which the signature effects are being assessed and the level of detail needed.

The sessions on Signature Phenomenology and Hyperspectral Signatures illustrated investigations on a great variety of signature features. Modelling and scene generation builds on these efforts. Some examples given were on work involving (hyper)-spectral measurements and theoretical work on the capabilities of sensors. Papers were presented on the effect of environmental conditions on signatures and their effect on sensor performance.

Finally, the sessions on Processing and Human Observer Performance discussed methods to assess the effect of signature management on detection and tracking of targets at a system level. Several aspects of sensor processing were shown. Bringing in new perspectives on processing from the field of anomaly detection in radiological research, as presented, can be stimulating to the research in electro-optical target detection.

A great variety of methods for assessing human observer performance was shown, which contributes to the understanding of the observation process. This also helps define the level at which signature effects are assessed. For example, the time needed to detect an object in a specific scene does not translate automatically into the effect of survivability on the next level. However, the discussions after the presentations emphasized this.

We would like to thank authors, the program committee, and session chairs for sharing their efforts and expertise to make this a successful, well-attended conference.

We also would like to thank SPIE and their dedicated staff for providing a wellsuited framework for the conference.

Karin U. Stein Ric H. M. A. Schleijpen 